\title{
Sentidos da ALB
}

\section{The meanings of ALB}

https://doi.org/10.34112/2317-0972a2020v38n79p105-108

\section{Ezequiel Theodoro da Silva ${ }^{1}$}

\section{SENTIDO: MARCHE!}

Nos idos de 1978, em ares e tempos pesados de ditadura, desafiamos o sistema implementando o $1^{\circ}$ COLE, que buscava assentar e "colar" outras preocupações a respeito da realidade educacional brasileira. Apontar para outras visões e concepções da leitura que não fossem a do "sentido: marche!" ideológico, autoritário e monovalente que os coturnos e as baionetas nos impunham naquele período tão sufocante. Houve uma resposta calorosa dos educadores ao nosso evento, dando a entender que as convicções e as ordens unidas dos quartéis se contrapunham ao desejo por democracia no país - ia se desenhando então uma outra leitura de realidade nas retinas de muitos educadores brasileiros. Em 1979 repetimos o COLE, aglutinando mais vozes em torno da insatisfação, do protesto e da denúncia; reforçava-se naquele ano um horizonte mais nítido de construção de uma sociedade com outras possibilidades de exercício do poder, em direção contrária, antagônica, contraposta ao "sentido-marche" autoritarista. Em 1981, pudemos ver que o movimento social já não mais acompanhava o rumo único imposto pela ditadura com o seu bater

1. Professor aposentado da Faculdade de Educação - Unicamp. Atuou como Presidente da Associação de Leitura do Brasil -ALB nas gestões: 1981/1983;1984/1985;1986/1987;1990/1991;2007/2008. 
de calcanhares e de continências. Trouxemos Paulo Freire de volta para abrir o $3^{\circ}$ COLE em 1981 e nos fazer acompanhar pelo seu modo de conceber a leitura da vida, da palavra e do mundo. Juntando sonhos e esperanças, trabalhando à revelia dos donos do poder, fundamos, no mesmo ano, a ALB com o objetivo maior de lutar pela democratização da leitura no Brasil.

\section{Pré-SENTIDo}

De pressentimento, passando pela constatação, caindo na evidência histórica: a leitura, tal qual a cultura e a educação, nunca foi uma preocupação relevante para os donos dos vários e enquistados poderes brasileiros. A drástica paisagem da leitura é reiterada de ano para ano, sem que sejam elaboradas e implantadas políticas, programas, ações sadias ou saneadoras em direção a uma mudança que nos leve a chegar a um outro patamar, o patamar onde a leitura seja, igual à educação, um direito e uma prática essencial ao exercício da cidadania. A razão de ser da ALB, um dos porquês dela se manter de pé é o descaso das autoridades na direção de um povo culto, capaz, crítico. Talvez seja por isso mesmo que, em 30 anos de existência, a ALB, mesmo produzindo e tendo produzido trabalhos importantíssimos para novos rumos e sentidos para a leitura nacional, jamais foi convocada, em termos de voz e vez, para somar contribuições que conduzissem as práticas de leitura, fosse onde fosse, para um patamar mais digno, condizente e edificante. Práticas de leitura crítica, capazes de por abaixo, de "espatifar o entulho arcaico, corrupto e patrimonialista que o Estado [brasileiro] abriga" ${ }^{2}$. Pré-sentido, pressentimento de que a ALB terá vida longa, longuíssima, até que a grande maioria da população brasileira, possuindo uma outra mirada de - e para a - sua capacidade leitora, possa dar o devido sentido, por exemplo, ao abraço de Lula em Paulo Maluf e o que isso significa em termos de conchavo, atraso, círculo vicioso, viciado e avacalhado. Por exemplo, da defesa do bicheiro e ladrão Carlinhos Cachoeira pelo seu advogado, ex-ministro da Justiça do Brasil, Márcio Thomaz Bastos. Sem dúvida, é preciso ler criticamente a realidade da "despolítica" brasileira, os pré-sentidos e os pressentimentos do que ainda está por vir, caso os cenários não forem outros...

2. JABOR, Arnaldo. As ideias não correspondem mais aos fatos. In: Jornal Correio Popular. Campinas, 17-julho-2012, p. C2. 
Sentindo o Sentido

Numa sociedade como a nossa, onde o espírito do associativismo e da solidariedade nunca foi lá uma coisa muito forte, $\mathrm{o}$ aniversário de 30 anos de uma entidade pode ser tomado como um fenômeno raro, que se distancia dos padrões de existência e sobrevivência das associações aqui nascidas por vontade da sociedade civil. Para entender a ossatura, a envergadura e a altivez da ALB, para sentir o seu sentido, é preciso buscar nos membros das suas diretorias, de 1981 até hoje, um "treco por dentro", "uma força bruta", um ímpeto combativo e construtivo na direção da continuidade de um projeto e na fantasia de, pela formação de leitores inteligentes, colocar a nossa sociedade no patamar da justiça social, do bem-comum, da felicidade que pode resultar da distribuição equitativa da riqueza. A marca registrada da ALB - talvez o seu motor e a sua energia - sempre foi e continua sendo - e oxalá continue sempre sendo - o seu desatrelamento dos governos e das administrações públicas, dos interesses menores e politiqueiros, do famoso e falso discurso de proteção aos trabalhadores e oprimidos desta terra; todas as diretorias souberam honrar o parágrafo único do Artigo $1^{\circ}$ dos seus estatutos: "É vedado aos associados bem como aos membros da Administração a utilização do nome da ALB para atividades religiosas, político-partidárias e quaisquer outras estranhas aos seus objetivos sociais." Assim, as pessoas, as equipes de pessoas que formaram as diferentes diretorias amorosamente deram muito de si, pressentiram, sentiram, cheiraram e degustaram as dificuldades do dia-a-dia de uma entidade que sempre andou sobre as suas próprias pernas, que nunca abriu as pernas e que, pela sua ação séria e transformadora, estende os seus braços e todo o seu corpo para leituras que sejam alternativas àquela que autoritariamente, ou que comercialmente pelo viés único do mercado, desejam o conformismo, a subserviência e/ou a reprodução da incultura da nossa população.

\section{Sentimento Sentido}

Hilário já se foi. Beteizabete já se foi. Milton já se foi. Bartolomeu já se foi. Outros cujos nomes me escapam não se foram, mas simplesmente se afastaram ou foram obrigados a partir pelas circunstâncias, tomaram outros caminhos para outras semeaduras. Por mais que se deseje individualizar ou endeusar ou totemizar as conquistas da ALB nesta ou naquela pessoa, neste ou naquele presidente, num ou noutro pesquisador, fenômeno que tem as suas raízes na visão ainda arraigada de se 
esculpir heróis e vilões para os fatos e fios da história, o meu sentimento sentido é o de que a Associação de Leitura do Brasil é uma realização de muitas cabeças, muitos braços, muitas mãos que, ou no terreno da cooperação ou no quintal de muitas brigas ou na esfera de vários desentendimentos ou mesmo inimizades duradouras, cresceu, ganhou cara e corpo e se robusteceu ao longo da sua existência. Cada qual, do seu jeito, ao seu modo, quinhaozão ou quinhaozinho, somaram em favor da história da ALB, dando-lhe resistência no tempo, tradição, identidade e, mais do que tudo, a dignidade de uma cidadela ou uma fortaleza de pessoas que pensam, lutam pela causa e pelas coisas da leitura no Brasil. E esse meu sentimento sentido, fortalecido a cada COLE, a cada novo/jovem integrante da ALB, a cada publicação editada, a cada novo leitor que se conquista é expresso num poema de Guimarães Rosa com o qual finalizo a minha intervenção nesta mesa e que saúda, com o mais puro sentimento de prazer, entusiasmo renovado e alegria, estes 30 anos da ALB.

\author{
Alongo-me \\ O rio nasce \\ toda a vida. \\ Dá-se \\ ao mar a alma vivida. \\ A água amadurecida, \\ a face \\ ida. \\ O rio sempre renasce \\ A morte é vida. ${ }^{3}$
}

3. ROSA, Guimarães. Alongo-me. In: Ave Palavra. RJ: Livraria José Olympio Editora, 1978, p. 45. 